\title{
The Phenomenon of The Month of Sela in The Indonesian Capital Market
}

\author{
Arini Putri Helanda ${ }^{1, a}$, Ani Wilujeng Suryani ${ }^{1, b^{*}}$ \\ ${ }^{1}$ Department of Accounting, Faculty of Economics, Universitas Negeri Malang \\ Jl. Semarang 5, Sumbersari, Kota Malang, East Java, Indonesia \\ e-mail: a ariniputri788@gmail.com, ${ }^{\text {b* }}$ ani.suryani@um.ac.id \\ * Corresponding Author
}

\begin{abstract}
Seasonal anomalies cause market inefficiency by affecting the mean and volatility of stock returns, and allow investors to obtain abnormal returns. In Indonesia, there is the month of Sela which is believed as an unlucky month so that many people avoid this month to hold ceremonial activities. As a result, the economy declines in the month of Sela and possibly, the return will also drop in this month. Therefore, this research aims to reveal whether the month of Sela is a seasonal anomaly. This research tested two hypotheses; the effect of the mean and volatility of price index return by using the GARCH model. To examine the effect of the month of Sela on the mean and volatility of return of price index, we collected the data on Indonesian Composite Index and 10 sectoral indices from 2009 to 2019 on three Javanese months, Sawal, Selo and Besar. In total, we collected 7.095 returns data. The month of Sela was a seasonal anomaly that the average and volatility of returns during the month of Sela were lower than those during the months of Sawal and Besar. These results also indicated that during the months of Sawal and Besar, the price index was more volatile than it was during the month of Sela. This research is useful for investors in considering their investment decisions to obtain an abnormal return. This research also contributes to the literature by adding new knowledge about seasonal anomalies that exist in Indonesia.
\end{abstract}

Keywords: Conditional Volatility, Javanese, Mean Return, Seasonal Anomalies, Sela

Article History: Received: September, 102020 Revised: September, 252020 Accepted: September, 302020

How to cite: Helanda, A. P., \& Suryani, A. W. (2020). The Phenomenon of The Month of Sela in The Indonesian Capital Market. Akrual: Jurnal Akuntansi, 12(1):65-79

DOI: https://doi.org/10.26740/jaj.v12n1.p65-79

\section{INTRODUCTION}

An efficient market is a market where all available information reflects the price of all securities that are traded (Caporale et al., 2016; Fama, 1970; Kalayil et al., 2019; Swamy \& Dharani, 2019). If a market is efficient, the price will change according to the random walk theory (RWT) and cannot be predicted (Fama, 1970; Toit et al., 2018; Wasiuzzaman \& AlMusehel, 2017), so that investors will not easily obtain abnormal return (Reddy et al., 2019). However, there is a phenomenon such as market anomaly that can make the market inefficient (Haggard et al., 2015; Levy, 1996; Reddy et al., 2019; Seif et al., 2017). Market 
anomaly is a situation where the performance of an equity or a group of equities deviates from the assumed efficient market hypothesis (Guerard \& Chettiappan, 2017; Halari, 2017; Latif et al., 2011). Seasonal anomaly is important to study because this anomaly is the most obvious in exposing market inefficiency (Halari, 2017; Mills \& Coutts, 1995). One form of the anomaly is a month of the year effect, which shows that the returns in certain months increase, and hence, there is an opportunity to obtain abnormal return (Compton et al., 2013; Floros \& Salvador, 2014; Lobão, 2019; MA, 2018), for example, the Ramadan effect. The Ramadan effect demonstrates an increase in returns during the month of Ramadan (Munusamy, 2018; Ozkan, 2017; Shahid et al., 2019) because the mood of investors during Ramadan is better, many decide to invest (Al-Khazali et al., 2017), and this causes an increase in the returns (Al-Khazali et al., 2017). Another example of seasonal anomaly is the January effect, in which the returns are higher than those in other months (Depenchuk et al., 2010; Easterday, 2015; Evbayiro-osagie, 2018; Kumar \& Pathak, 2016; Levy, 1996; Ozkan, 2017) because investors delay the sale of stocks until after the new year (Sahin et al., 2018). Calendar anomaly, apart from affecting the returns, also affects the volatility of the index return (Al-Khazali et al., 2017; Halari, 2017), such as in Ramadhan whereby market becomes more volatile (Ariss et al., 2011; Białkowski et al., 2013; Halari et al., 2018; Munusamy, 2018, 2019; Wasiuzzaman \& Al-Musehel, 2017).

Market inefficiency can also be caused by the existing behavior in the capital market (Riza et al., 2018; Robiyanto \& Puryandani, 2015) such as irrational actions of investors in the market (Aggarwal \& Mohanty, 2018; Burton \& Shah, 2013; Hermin \& Mahadwartha, 2018). Behavior and performance of an individual can also be influenced by culture (AlIssiss, 2015; Zhan, 2019) because culture is a belief or value that influence an individual's life, behavior, and decision making (Al-Ississ, 2015; Wasiuzzaman \& Al-Musehel, 2017; Zhan, 2019). When people of a country uphold cultural values, investors tend to imitate the behavior of others, which can increase stock price, as is the case with developing countries (Zhan, 2019). However, many investors tend to take various actions to gain profit, regardless of whether the action is rational or not (Robiyanto \& Puryandani, 2015) such as acting based on superstition (Robiyanto \& Puryandani, 2015). Cultural considerations and superstitions influence the process of behavior shaping in financial markets (Hermin \& Mahadwartha, 2018; Liu, 2013; Robiyanto \& Puryandani, 2015). For example, research on Friday 13 showed that the return on that day was lower (Robiyanto \& Puryandani, 2015) because people in countries influenced by Judeo-Christian beliefs consider Friday 13 an unlucky day (Robiyanto \& Puryandani, 2015). With this belief, many people avoid activities on Friday 13 so that one of the impacts is a lower return.

Based on prior research, this study is to investigate the existence of market anomaly in Indonesia which is the largest Muslim population in the world with $87.20 \%$ of the population is Muslim (Indonesia.go.id, 2020; World Population Review, 2020). Islam began to develop in Indonesia at the time of the fall of the Javanese Hindu-Buddhist kingdoms (Woodward, 1989). As a result of the establishment of the Islamic Mataram 
kingdom in $1578 \mathrm{AD}$ (Woodward, 1989), Islam grew and reached its peak during the era of Sultan Agung (Karaton Ngayogyakarta Hadiningrat, 2019; Musonnif, 2016; Woodward, 1989). To support the spread of Islam, the Islamic preachers tended to preach in a tolerant pattern while still adopting the old culture and acculturating Islamic values to local values (Musonnif, 2016). One form of the acculturation is the Javanese calendar (Karaton Ngayogyakarta Hadiningrat, 2019; Rizkianingtyas, 2018; Wahyudi, 2014).

The Javanese calendar is a fusion of Hindu-Buddhist culture - the Saka calendar with Islamic culture - the Hijri calendar (Karaton Ngayogyakarta Hadiningrat, 2019; Robiyanto \& Puryandani, 2015). The establishment of the Javanese calendar did not change the existing order. It simply continued the Saka year and replaced its calculation based on the motions of the moon (Karaton Ngayogyakarta Hadiningrat, 2019; Proudfoot, 2007). The purpose of establishing the Javanese calendar was to overcome the problem of cultural differences between Muslims who adhered to syncretistic Islam (Kejawen) and Muslims who adhered to normative Islam (Rizkianingtyas, 2018; Wahyudi, 2014). This calendar was created to form a sense of unity among the people of Mataram in the face of Dutch colonialism (Rizkianingtyas, 2018; Wahyudi, 2014) and to adjust the Saka calendar with the Hijri calendar so that the celebration of Eid al-Adha could be carried out simultaneously (Anderson, 2009; Karaton Ngayogyakarta Hadiningrat, 2019). The Javanese calendar has twelve months whose names were acculturated from Arabic and adapted for Javanese speaking (Karaton Ngayogyakarta Hadiningrat, 2019; Musonnif, 2016; Rizkianingtyas, 2018; Wahyudi, 2014).

In Indonesia, the Javanese are the largest ethnic group with a percentage of $40.05 \%$ (Badan Pusat Statistik, 2015) and they are politically and culturally dominant (Efferin \& Hopper, 2007; Mulder, 1994; Sarsito, 2006). The Javanese people believe that certain months must be avoided for a celebration, such as the month of Sela, which means "between times (bulan apit)" because this month is between the two months, Sawal and Besar (Musonnif, 2016; Nurfitria \& Hidayati, 2011). However, there was also researchers who argued that the meaning of Sela is silo, similar to the meaning of the month of Dzulqa'dah (Musonnif, 2016; Nurfitria \& Hidayati, 2011). Silo comes from the word "bersila", which is sitting cross-legged like sitting position of dhikr (recollection) (Musonnif, 2016; Nurfitria \& Hidayati, 2011). As a result of this belief, Javanese people avoid the month of Sela as a month to hold a celebration (AA, 2016; Riza et al., 2018; Tjakraningrat, 2017) and are encouraged to purify themselves or perform ritual ceremony of selametan, such as bersih desa (the cleansing of the village) ritual (Geertz, 1976; Hamdi, 2018). The purpose of bersih desa ritual is to ask God to protect all residents in the neighborhood and to preserve nature. It is also an expression of gratitude to God (Abdurrohman, 2015; Adji, 2017; Geertz, 1976; Samidi, 2016).

The impact of this belief is a decline in the economic performance of the society during the month of Sela. The decline in the economic performance can be seen from the decline in sales turnover (Nurfitria \& Hidayati, 2011), the decline in the price of chicken in 
the market (Rohmatillah, 2019), and the small number of people who hold wedding ceremony in the month of Sela (AA, 2016; Riza et al., 2018). Meanwhile, economic performance is clearly better in the month before and after the month of Sela, indicated by an increase in the use of catering services in the month of Besar because there are many celebration events (Nurfitria \& Hidayati, 2011). Prior study has discovered that the months of Besar and Sawal were the first and second most favorite months for people to hold a wedding ceremony with a percentage of $22 \%$ and $17 \%$ (Riza et al., 2018). The level of consumption has also increased because there are two major holidays for Muslims, Eid alAdha and Eid al-Fitr, which make financial expenditure a lot in those two months. As consequences, Sawal has positive effect on the index return because of positive investors' mood during the month, resulted in an increase of returns (Shah et al., 2017). However, Zul-hijjah effect (Besar effect) brings a negative effect the index return because of a low trading activity during this month (Akhter et al., 2015). These two months could cause abnormal returns in the Indonesian capital market (Andriyani et al., 2018; Hinawati, 2016). This may occur because of public optimism and an increase in social mood so that trading activity in the Indonesian capital market increases (Andriyani et al., 2018).

This study aims to examine empirically whether the month of Sela has an impact on the mean and volatility of indices' returns in the Indonesian capital market, compare to Sawal and Besar. The study adds new knowledge and references for further research, especially in seasonal anomalies. The uniqueness of this research is that it examines the phenomenon of the month of Sela in the Javanese calendar. Previous research has found that there was no effect of the Javanese calendar (Robiyanto \& Puryandani, 2015), but there were also those who discovered a partial effect of the Javanese calendar on returns in Indonesia (Hermin \& Mahadwartha, 2018). However, the previous research was based on the days in the Javanese calendar, which are referred to as "pasaran", and not based on the months, so further research on the effects of the Javanese calendar, which is based on the months, is quite crucial. Therefore, the hypothesis in the study are:

\section{$H_{1}:$ There are effects of the month of Sela on the mean of price index return. $\mathrm{H}_{2}$ : There are effects of the month of Sela on the volatility of the price index return.}

This research was conducted by testing the composite stock price index and ten sectoral indices in the Indonesian capital market by using the GARCH test $(1,1)$. The remainder of this paper is organized as follows. The procedures of data collection and methodology that were used in this study will be presented in research method section, followed by the results of data analysis and discussion. The final section provides conclusions, implications, limitations, and recommendations for future research.

\section{RESEARCH METHOD}

This research employs data in the form of daily price indices in ten sectoral indices and Jakarta Composite Index (JCI) during, before, and after the month of Sela with a time 
period from 2009 to 2019. Data were obtained via Yahoo Finance. We chose 2009 because the stock market began to slowly recover after the 2008 global financial crisis (Munusamy, 2019; Uchoa, 2018). The daily index was employed because it is the most appropriate frequency to analyze and with a minimum period of four years, daily data are sufficient to apprehend the important features of the capital market (Munusamy, 2019; Taylor, 1986). Therefore, the period of 11 years is considered sufficient to reflect the important features of financial data.

The impact of the month of Sela on the return and volatility of the market index can be observed via the following model:

$R_{i}=\alpha+\beta_{1} D_{1 i}+\varepsilon_{t}$

$R_{i}=\alpha+\beta_{2} D_{2 i}+\varepsilon_{t}$

$R_{i}$ is market index return. $D_{1 i}$ is dummy variabel, 1 Sela 0 Sawal. $D_{2 i}$ is dummy variabel, 1 Sela 0 Besar. $\alpha$ is the contant in the equation, $\varepsilon_{t}$ is an error-term, $\beta_{1}$ and $\beta_{2}$ are the coefficients.

The data of this study are not normal, have autocorrelation, and heteroscedasticity, and hence, ordinary least squares will not provide the best estimate. To overcome this problem, GARCH test was conducted. Prior to GARCH, the ARCH-LM test were performed on time series data. GARCH model $(1,1)$ is a GARCH model where the return value depends on the previous unexpected return and t-1 volatility (lag 1). The use of the GARCH model $(1,1)$ is considered sufficient for most financial data (Engle, 2001), so the GARCH model $(1,1)$ was used in this study (Bachmann et al., 2019; Bokpin, 2016; Dixit et al., 2010; Munusamy, 2018; Seif et al., 2017). Thus, the GARCH $(1,1)$ estimation technique is considered quite appropriate to test the impact of the month of Sela on the mean and volatility of returns of indices in the market. The following GARCH $(1,1)$ model was estimated:

Mean equation:

$R_{i}=c+\omega_{1} R_{t-1}+\eta_{1} \varepsilon_{t-1}+\beta_{1} D_{1 i}+\varepsilon_{t}$

$R_{i}=c+\omega_{1} R_{t-1}+\eta_{1} \varepsilon_{t-1}+\beta_{2} D_{2 i}+\varepsilon_{t}$

Where:

$\varepsilon_{t}^{2} \mid \Omega_{t-1} \sim\left(O, \sigma_{t}^{2}\right)$

Variance equation:

$\sigma_{t}^{2}=\alpha_{0}+\alpha_{1} \varepsilon_{t-1}^{2}+\beta_{1} \sigma_{t-1}^{2}+\beta_{1} D_{1 i}$

$\sigma_{t}^{2}=\alpha_{0}+\alpha_{1} \varepsilon_{t-1}^{2}+\beta_{1} \sigma_{t-1}^{2}+\beta_{2} D_{2 i}$

Equations (3) and (4) explain the results of test on returns where $R_{i}$ is market index return. $R_{i-t}$ is return $\mathrm{t}-1, \varepsilon_{t-1}$ is volatility $\mathrm{t}-1$, and $c$ is the contant in the equation. Equations (6) and (7) explain the results of test on volatility where $\varepsilon_{t-1}^{2}$ is residual t-1 and $\sigma_{t-1}^{2}$ is variance t-1. $\omega_{1}, \eta_{1}, \beta_{1}$, and $\beta_{2}$ are coefficients. $D_{1 i}$ is dummy variabel, 1 Sela 0 Sawal, $D_{2 i}$ is dummy variabel, 1 Sela 0 Besar, and $\varepsilon_{t}$ is an error-term. The conditional variance in equation (5) is the value of the lagged-one conditional variance (GARCH, $\sigma t^{2}$ ) 
Helanda \& Suryani, The Phenomenon of The Month of Sela....

and the linear function of the square root of the previous period ( $\left.\mathrm{ARCH}, \varepsilon_{t}{ }^{2}-1\right)$. To know whether the GARCH $(1,1)$ estimation result model is good enough to model the data, further testing of heteroskedasticity can be conducted using the ARCH-LM test and autocorrelation should be observed basen on the p-value of Correlogram-Q-statistics residual (Wasiuzzaman \& Al-Musehel, 2017).

\section{RESULTS AND DISCUSSION}

Table 1 shows the comparison of returns in those three months. The majority of returns were lower in Sawal than in Sela. This can be seen from the mean return, which had a negative value in Sawal, except for the JKINFA and JKMING indices. The same thing also happened in the month of Besar where the majority of price index returns were lower than in the month of Sela. This was indicated by the majority of the mean values of returns that were negative in the month of Besar, except for the JKAGRI index. However, it cannot be concluded that the month of Sela had a higher mean return on index than Sawal and Besar did. This was because the index data were not normal and had autocorrelation and heteroscedasticity so that it was necessary to do the GARCH test whose results are reported in the GARCH test section $(1,1)$ for the mean return.

Table 1. Descriptive statistics

\begin{tabular}{|c|c|c|c|c|c|c|c|c|c|}
\hline \multirow[b]{2}{*}{ Variable } & \multicolumn{3}{|c|}{ Sawal } & \multicolumn{3}{|c|}{ Sela } & \multicolumn{3}{|c|}{ Besar } \\
\hline & Min & Max & $\begin{array}{c}\text { Mean } \\
\text { (Std Dev) }\end{array}$ & Min & Max & $\begin{array}{c}\text { Mean } \\
\text { (Std Dev) }\end{array}$ & Min & $\operatorname{Max}$ & $\begin{array}{c}\text { Mean } \\
\text { (Std Dev) }\end{array}$ \\
\hline JKSE & -0.0930 & 0.0465 & $\begin{array}{r}-0.0002 \\
(0.0146)\end{array}$ & -0.0581 & 0.0454 & $\begin{array}{r}0.0009 \\
(0.0123)\end{array}$ & -0.0383 & 0.0318 & $\begin{array}{r}-0.0003 \\
(0.0110)\end{array}$ \\
\hline JKAGRI & -0.0791 & 0.0748 & $\begin{array}{r}-0.0003 \\
(0.0171)\end{array}$ & -0.0896 & 0.0484 & $\begin{array}{r}-0.0002 \\
(0.0167)\end{array}$ & -0.5453 & 0.5453 & $\begin{array}{r}0.0001 \\
(0.0540)\end{array}$ \\
\hline JKBIND & -0.1418 & 0.0905 & $\begin{array}{r}-0.0008 \\
(0.0235)\end{array}$ & -0.0799 & 0.0535 & $\begin{array}{r}0.0016 \\
(0.0176)\end{array}$ & -0.0468 & 0.0661 & $\begin{array}{r}0.0004 \\
(0.0155)\end{array}$ \\
\hline JKCONS & -0.0746 & 0.0483 & $\begin{array}{r}-0.0003 \\
(0.0161)\end{array}$ & -0.0370 & 0.0529 & $\begin{array}{r}0.0006 \\
(0.0139)\end{array}$ & -0.0426 & 0.0478 & $\begin{array}{r}0.0002 \\
(0.0131)\end{array}$ \\
\hline JKFINA & -0.3286 & 0.3378 & $\begin{array}{r}-0.0003 \\
(0.0379)\end{array}$ & -0.0703 & 0.0710 & $\begin{array}{r}0.0017 \\
(0.0146)\end{array}$ & -0.0425 & 0.0442 & $\begin{array}{r}-0.0002 \\
(0.0131)\end{array}$ \\
\hline JKINFA & -0.0827 & 0.0428 & $\begin{array}{r}0.0004 \\
(0.0151)\end{array}$ & -0.0494 & 0.0448 & $\begin{array}{r}0.0001 \\
(0.0123)\end{array}$ & -0.0395 & 0.0384 & $\begin{array}{r}-0.0002 \\
(0.0117)\end{array}$ \\
\hline JKMING & -0.1016 & 0.0685 & $\begin{array}{r}0.0018 \\
(0.0180)\end{array}$ & -0.0618 & 0.0636 & $\begin{array}{r}0.0000 \\
(0.0170)\end{array}$ & -0.0511 & 0.0342 & $\begin{array}{r}-0.0011 \\
(0.0146)\end{array}$ \\
\hline JKMISC & -0.0959 & 0.0624 & $\begin{array}{r}-0.0014 \\
(0.0211)\end{array}$ & -0.0728 & 0.0878 & $\begin{array}{r}0.0013 \\
(0.0198)\end{array}$ & -0.0752 & 0.0853 & $\begin{array}{r}-0.0013 \\
(0.0196)\end{array}$ \\
\hline JKMNFG & -0.0903 & 0.0559 & $\begin{array}{r}-0.0007 \\
(0.0168)\end{array}$ & -0.0520 & 0.0547 & $\begin{array}{r}0.0010 \\
(0.0137)\end{array}$ & -0.2074 & 0.2085 & $\begin{array}{r}-0.0001 \\
(0.0238)\end{array}$ \\
\hline JKPROP & -0.0738 & 0.0493 & $\begin{array}{r}-0.0009 \\
(0.0175)\end{array}$ & -0.0661 & 0.0879 & $\begin{array}{r}0.0006 \\
(0.0157)\end{array}$ & -0.0393 & 0.0309 & $\begin{array}{r}-0.0003 \\
(0.0123)\end{array}$ \\
\hline JKTRAD & -0.0728 & 0.0418 & $\begin{array}{r}-0.0010 \\
(0.0169) \\
\end{array}$ & -0.0488 & 0.0879 & $\begin{array}{r}0.0009 \\
(0.0149) \\
\end{array}$ & -0.0393 & 0.0496 & $\begin{array}{r}0.0005 \\
(0.0133) \\
\end{array}$ \\
\hline
\end{tabular}

Source: Author's Calculation

Autocorrelation test and ARCH-LM test need to be done again after the GARCH test $(1,1)$ is carried out in order to ensure that the data do not experience autocorrelation and heteroskedasticity. The results of the autocorrelation test and the ARCH-LM test showed that the data had no autocorrelation and heteroskedasticity, but the results of the two tests 
were not shown due to space limitations. Table 2 shows that the month of Sela had a significant effect on the mean return of JKAGRI and had marginal effect on the return of JKMING. JKAGRI and JKMING had lower returns in the month of Sela than in the month of Sawal at $0.25 \%$ and $0.27 \%$.

Table 2. GARCH $(1,1)$ results

\begin{tabular}{lcll}
\hline \multicolumn{4}{c}{ Mean Equation } \\
\hline Variable & $\mathbf{C}$ & $\begin{array}{c}\mathbf{D}_{1} \\
(\text { Sela } \text { vs } \text { Sawal })\end{array}$ & $\begin{array}{c}\mathbf{D}_{\mathbf{2}} \\
\text { (Sela } \text { vs Besar })\end{array}$ \\
\hline JKSE & 0.001204 & -0.000766 & 0.001259 \\
JKAGRI & 0.002724 & $-0.002500^{* * *}$ & $-0.001434^{*}$ \\
JKBIND & 0.002123 & -0.001059 & 0.000933 \\
JKCONS & 0.000015 & -0.000506 & 0.000314 \\
JKFINA & 0.000493 & 0.000917 & $0.002520^{*}$ \\
JKINFA & 0.000653 & 0.000257 & 0.000761 \\
JKMING & $0.002417^{+}$ & $-0.002679^{+}$ & 0.001068 \\
JKMISC & -0.000965 & 0.001337 & 0.001784 \\
JKMNFG & 0.000664 & -0.000394 & 0.002703 \\
JKPROP & 0.000719 & -0.000199 & 0.000339 \\
JKSE & 0.000383 & 0.000615 & 0.000763 \\
\hline \hline Note: ***,*, Statistical significant at $0.01,5$, and 10 percent levels. \\
Source: Author's Calculation
\end{tabular}

Table 2 also shows that the month of Sela had a significant effect on the mean return of JKAGRI. JKAGRI had a lower return of $0.14 \%$ in Sela than in Besar. However, the month of Sela turned out to have a positive influence on JKFINA. The JKFINA index had a higher mean return value of $0.25 \%$ in Sela than in Besar. Thus, $\mathrm{H}_{1}$, which states that there are effects of the month of Sela on the mean of price index return, cannot be rejected.

The results of the analysis showed that the month of Sela had a negative effect on the mean return on the JKAGRI and JKMING indices, but had a positive effect on JKFINA. The negative effect was indicated by a decrease in the return of JKAGRI index in the month of Sela by comparing the returns in the months of Sawal and Besar. This happened because the mean value of return was lower in the month of Sela than in the months of Sawal and Besar. The lower mean value of return was due to the decline in public consumption during the month of Sela (AA, 2016; Nurfitria \& Hidayati, 2011; Riza et al., 2018; Rohmatillah, 2019) so that it might reduce the number of sales of agro-industrial companies. JKAGRI comprises companies engaged in agro-industry. A decrease in the number of sales could affect returns so that the month of Sela had a negative effect on the return of JKAGRI index. In addition, $58.46 \%$ of constituent companies of the JKAGRI index recorded a decrease in returns during the month of Sela compared than in the months of Sawal and Besar. With this, it is possible that the JKAGRI index will also experience a decline of return during the month of Sela. 
In line with the JKAGRI index, the month of Sela also had a negative effect on the mean return of the JKMING index, indicating that the mean return was lower in the month of Sela than in the month of Sawal. In addition, the decline in mean returns could also be due to the fact that JKMING comprises companies engaged in supply of fuels for industrial use. During the month of Sela, private consumption decreased and industrial production decreased. With a decrease in the production, the sales of fuel also decreased. A decrease in the sales can affect returns so that the month of Sela had a negative effect on the mean return on the JKMING index. Furthermore, $60.62 \%$ of constituent companies that constituted the JKMING index also experienced decreasing returns during the month of Sela than during the month of Sawal. Therefore, the return of JKMING index also declined in the month of Sela.

Unlike JKAGRI and JKMING, the month of Sela had a positive effect on the mean return of JKFINA index. Descriptive statistics indicated that there was an increase in the mean return in the month of Sela than in the month of Besar. The increase in the mean return was also because $76.76 \%$ of constituent companies that constituted JKFINA experienced increasing returns in the month of Sela rather than in the month of Besar. Thus, the JKFINA index will also experience increasing return in the month of Sela rather than in the month of Besar.

The results of this research also support the results of research by Al-Khazali (2008), Ariss et al. (2011), Białkowski et al. (2013), Depenchuk et al. (2010), Halari et al. (2018), Jaisinghani (2016), Munusamy (2019), Shahid et al. (2019), Wasiuzzaman and Al-Musehel (2017), which discovered that there was seasonal anomaly, which is included in the category of month of the year, namely, the month of Sela. The results of this research also discovered that the month of Sela might shape investor behavior due to cultural influences (Al-Ississ, 2015; Wasiuzzaman \& Al-Musehel, 2017; Zhan, 2019). If there is a change in investor behavior, many investors tend to take various actions to gain profits on the capital market (Hermin \& Mahadwartha, 2018; Liu, 2013; Robiyanto \& Puryandani, 2015), which can cause a difference in returns in the months of Sela, Sawal, and Besar.

The results of this research contradicted EMH. EMH states that an efficient market is a market where the prices of all securities reflect all available information (Bokpin, 2016; Fama, 1970; Musnadi et al., 2018; Reddy et al., 2019; Seif et al., 2017). Meanwhile, the results of this research indicated the opposite. The capital market in Indonesia is not yet an efficient market and the prices in the capital market do not reflect all available information. In addition, the results of this research also contradicted the concept of RDW. RDW states that if a market is efficient, then the price will move randomly and cannot be predicted (Fama, 1970; Toit et al., 2018; Wasiuzzaman \& Al-Musehel, 2017), so that investors will not easily obtain abnormal return (Reddy et al., 2019). However, the results of this research indicated the effect of the month of Sela, which caused prices to not change randomly and allowed investors to obtain abnormal returns. With the price index dropping during the 
month of Sela, investors are encouraged to buy stokes during the month of Sela and sell them when the price starts to rise again, for example, in the month of Besar.

Table 3 shows that the month of Sela affected the seven price indices (JKBIND, JKCONS, JKFINA, JKINFA, JKMING, JKMISC, and JKPROP), except for the JKSE, JKAGRI, JKMNFG, and JKTRAD indices. It meant that the month of Sela caused a difference in the volatility of returns on the seven indices. These seven indices had lower volatility values in the month of Sela than in the month of Sawal. Table 3 also illustrates that the month of Sela only affected three price indices (JKBIND, JKFINA, and JKMNFG). It meant that the month of Sela caused a difference in the volatility of returns on the three indices. These three indices had lower volatility values in the month of Sela than in the month of Besar. Table 3 portrays that the p-value of all indices in ARCH and GARCH models was significant, so it can be said that the volatility of all indices was influenced by unexpected returns and volatility in the previous period. Thus, $\mathrm{H}_{2}$, which states that there are effects of the month of Sela on the volatility of the price index return, cannot be rejected.

Table 3. GARCH $(1,1)$ volatility results

\begin{tabular}{|c|c|c|c|c|c|}
\hline \multicolumn{6}{|c|}{ Variance equation } \\
\hline Variable & $\mathbf{C}$ & ARCH & GARCH & $\begin{array}{c}\mathrm{D}_{1} \\
\text { (Sela vs Sawal) }\end{array}$ & $\begin{array}{c}\mathrm{D}_{2} \\
\text { (Sela vs Besar) }\end{array}$ \\
\hline JKSE & $0.000004 * *$ & $0.166157 * * *$ & $0.811591 * * *$ & -0.000000 & -0.000000 \\
\hline JKAGRI & $0.000107 * * *$ & $2.737149 * * *$ & $-0.000573 * * *$ & 0.000001 & -0.000012 \\
\hline JKBIND & $0.000011 * * *$ & $0.191424 * * *$ & $0.740090 * * *$ & $-0.000039 * * *$ & $-0.000017^{*}$ \\
\hline JKCONS & $0.000002 * *$ & $0.128974 * * *$ & $0.803164 * * *$ & $-0.000011^{*}$ & 0.000000 \\
\hline JKFINA & $0.000365 * * *$ & $0.240248 * * *$ & $0.567321 * * *$ & $-0.000347 * * *$ & $-0.000009 *$ \\
\hline JKINFA & $0.000001 * *$ & $0.095166^{* * *}$ & $0.880459 * * *$ & $-0.000009 * * *$ & 0.000004 \\
\hline JKMING & $0.000020 *$ & $0.076360 * * *$ & $0.869104 * * *$ & $-0.000011^{*}$ & -0.000001 \\
\hline JKMISC & $0.000026^{*}$ & $0.103939 * * *$ & $0.846180 * * *$ & $-0.000012^{+}$ & -0.000007 \\
\hline JKMNFG & $0.000012 *$ & $0.192093 * * *$ & $0.752612 * * *$ & 0.000004 & $-0.000061 * * *$ \\
\hline JKPROP & $0.000018 * * *$ & $0.188217 * * *$ & $0.764261 * * *$ & $-0.000010 *$ & -0.000000 \\
\hline JKTRAD & $0.000016^{* * *}$ & $0.154296 * * *$ & $0.786525 * * *$ & -0.000006 & -0.000006 \\
\hline
\end{tabular}

The results of the analysis demonstrated that there was a negative effect of the month of Sela on the volatility of returns of eight indices: JKBIND, JKCONS, JKFINA, JKINFA, JKMING, JKMISC, JKMNFG, and JKPROP. The results showed that the eight indices experienced less volatility in the month of Sela than in the month of Sawal. Furthermore, the volatility of the JKBIND and JKFINA indices also fell in the month of Sela than in the month of Besar. The results of this research were similar to those of Al-Hajieh et al. (2011), Al-Khazali et al. (2017), Białkowski et al. (2013), Halari (2017), Munusamy (2018, 2019), Wasiuzzaman and Al-Musehel (2017) where there was a seasonal anomaly, which is included in the category of month of the year and can affect the return volatility.

The decreasing volatility on several indices might be caused by changes in investor behavior. During the month of Sela, many people reduce economic activity and are encouraged to do spiritual cleansing (Geertz, 1976; Hamdi, 2018). Investors may have 
been reducing their activities in the Indonesian capital market so that trading activity has decreased and thus, causeing volatility to fall. These results are in line with results of research by Al-Khazali et al. (2017), which stated that the volatility of returns could decrease due to changes in investor behavior. However, Al-Khazali et al. (2017) discoverd that changes in behavior were caused by investors doing more worship activities than trading on the stock market during the month of Ramadan so that stock trading activity fell. Thus, there was a similarity between the month of Sela and the month of Ramadan in which investors reduced their trading activity more, which can lead to decreasing volatility.

In addition, the decrease in the volatilities of the JKBIND, JKCONS, JKFINA, JKINFA, JKMING, JKMISC, and JKPROP indices could also be due to the lower standard deviation values in the month of Sela than in the month of Sawal. The standard deviation value of JKMNFG index was also lower in the month of Sela than in the month of Besar. The decreasing volatility could also be caused by $88.36 \%$ and $74.33 \%$ of the constituent companies of JKCONS and JKMING that experienced a decrease in the mean volume during the month of Sela than during the month of Sawal. In line with the JKCONS and JKMING indices, the mean volume value of $93.75 \%$ of companies that constituted JKBIND index also decreased in the month of Sela than in the months of Sawal and Besar. The lower mean volume value indicates the low intensity of stock trading incorporated in the index, so that the volatility of the JKBIND, JKCONS and JKMING indices also decreased during the month of Sela.

\section{CONCLUSION}

This research aims to discover whether there are effects of the month of Sela on the mean and volatility of stock price index returns. This research employed the JCI daily data and ten sectoral indices in the period 2009-2019 and provides several conclusions. First, this research discovered that there was a seasonal anomaly, namely the month of Sela, which could affect the mean and volatility of stock price index returns in the Indonesian capital market. This finding is in line with previous research, which discovered seasonal anomaly in the category of month of the year that could affect the mean return and volatility. Second, the month of Sela had negative and positive effects on the mean return. If it has a negative effect, then there is a decrease in return in the month of Sela. However, if it has a positive effect, then there will be an increase in return in the month of Sela. The JKAGRI and JKMING indices were indices whose returns decreased during the month of Sela than during the month of Sawal. However, the JKFINA index showed increasing returns in the month of Sela rather than in the month of Besar. Third, the month of Sela also negatively affected most of the volatilities of returns on the price index. It indicated that most indices had decreased volatility during the month of Sela than in Sawal. In addition, the decrease in volatility indicated that the month of Sela was no more volatile than the months of Sawal and Besar.

In addition, these findings confirm that the month of Sela can change investor behavior based on culture. The results contradict the efficient market hypothesis and random walk theory so that index return in the future can be predicted. If the index return in the future can be predicted, it will allow investors to obtain abnormal return. Based on 
this research, investors can make decisions in determining their investment strategy so that it is possible for them to obtain abnormal returns. Investors are encouraged to buy stocks listed in the JKAGRI and JKMING indices during the month of Sela because the price index drops and to sell them when the price starts to rise again, namely during the month of Besar. The results of this research contribute to the literature on seasonal anomalies in the category of month of the year by considering the effect of the month of Sela on the mean and volatility of price index returns in Indonesia.

This research employed the GARCH model $(1,1)$ but the model used in this study was the simplest GARCH model. For future research, it is recommended to use other GARCH models such as the GARCH-M, TGARCH, ARFIMA-FIGARCH models in order to compare the results. In addition, this research used a sample of stock price index without considering seasonal anomalies on stock prices. The next research is suggested to tets the price index and the stock price of the constituent companies of the index to determine the consistency of the effect of the month of Sela.

\section{ACKNOWLEDGMENT}

This work was supported by the Universitas Negeri Malang under the PNBP research grant No. 4.3.23/UN32.14.1/LT/2020.

\section{REFERENCES}

Abdurrohman, M. (2015). Memahami Makna-Makna Simbolik Pada Upacara Adat Sedekah Laut di Desa Tanjungan Kecamatan Kragan Kabupaten Rembang. The Messenger, $\operatorname{VII}(1), 27-34$.

Adji, H. (2017). Cara Pandang Dunia Warga Arjowilangun dalam Upacara Bersih Desa. Mozaik Humaniora, 17(1), 72-85.

Aggarwal, D., \& Mohanty, P. (2018). Do Indian Stock Market Sentiments Impact Contemporaneous Returns? South Asian Journal of Business Studies, 7(3), 332-346.

Akhter, A., Sandhu, A., \& Butt, S. (2015). Islamic Calendar Effect on Market Risk and Return Evidence from Islamic Countries. Journal of Business and Financial Affairs, 4(2), 1-5.

Al-Hajieh, H., Redhead, K., \& Rodgers, T. (2011). Investor Sentiment and Calendar Anomaly Effects: A Case Study of The Impact of Ramadan on Islamic Middle Eastern Markets. Research in International Business and Finance, 25(3), 345-356.

Al-Ississ, M. (2015). The Holy Day Effect. Journal of Behavioral and Experimental Finance, 5, 60-80. https://doi.org/10.1016/j.jbef.2015.02.007

Al-Khazali, O. (2014). Revisiting Fast Profit Investor Sentiment and Stock Returns During Ramadan. International Review of Financial Analysis.

Al-Khazali, O., Bouri, E., Roubaud, D., \& Zoubi, T. (2017). The Impact of Religious Practice on Stock Returns and Volatility. International Review of Financial Analysis, $52,172-189$.

Al-Khazali, O. M. (2008). The Impact of Thin Trading on Day-of-The-Week Effect: Evidence from The United Arab. Review of Accounting and Finance, 7(3), 270-284. 
Helanda \& Suryani, The Phenomenon of The Month of Sela....

Anderson, B. R. O. (2009). Mythology and The Tolerance of The Javanese. United Kingdom UK: Equinox Publishing.

Andriyani, H., Syaifuddin, D, T., Sujono, Saleh, S., Dali, N., Hamid, W., Budi, N., \& Patwayati. (2018). Stock Return Analysis Before and After Islamic Holidays (Study on Consumer Goods Industry Sector of Indonesian Stock Exchange). Proceeding Book 1st International Multidiciplinary Research Convention, 1-14.

Ariss, R. T., Rezvanian, R., \& Mehdian, S. M. (2011). Calendar Anomalies in The Gulf Cooperation Council Stock Markets. Emerging Markets Review, 12, 293-307.

Bachmann, C., Tegtmeier, L., Gebhardt, J., \& Steinborn, M. (2019). The "Sell in May" Effect: An Empirical Investigation of Globally Listed Private Equity Markets. Managerial Finance, 45(6), 793-808.

Badan Pusat Statistik. (2015, November 18). Mengulik Data Suku di Indonesia. Badan Pusat Statistik. Retrieved from: https://www.bps.go.id/news/2015/11/18/127/mengulik-data-suku-di-indonesia.html

Białkowski, J., Bohl, M. T., Kaufmann, P., \& Wisniewski, T. P. (2013). Do Mutual Fund Managers Exploit The Ramadan Anomaly? Evidence from Turkey. Emerging Markets Review, 15, 211-232.

Białkowski, J., Etebari, A., \& Wisniewski, T. P. (2012). Fast profits: Investor Sentiment and Stock Returns during Ramadan. Journal of Banking and Finance, 36(3), 835845.

Bokpin, L. M. G. A. (2016). Time Your Investment on The Ghana Stock Exchange (GSE). African Journal of Economic and Management Studies, 7(2), 256-267.

Burton, E. T., \& Shah, S. N. (2013). Behavioral Finance: Understanding The Social, Cognitive, and Economic Debates. Wiley.

Caporale, G. M., Gil-Alana, L. A., \& Plastun, A. (2016). The Weekend Effect: An Exploitable Anomaly in The Ukrainian Stock Market? Journal of Economic Studies, 43(6), 954-965. https://doi.org/10.1108/JES-09-2015-0167

Compton, W., Kunkel, R. A., \& Kuhlemeyer, G. (2013). Calendar Anomalies in Russian Stocks and Bonds. Managerial Finance, 39(12), 1138-1154.

Depenchuk, I. O., Compton, W. S., \& Kunkel, R. A. (2010). Ukrainian Financial Markets: An Examination of Calendar Anomalies. Managerial Finance, 36(6), 502-510.

Dixit, A., Yadav, S. S., \& Jain, P. . (2010). Informational Efficiency of Implied Volatilities of S\&P CNX Nifty Index Options: A study in Indian Securities Market. Journal of Advances in Management Research, 7(1), 32-57.

Easterday, K. E. (2015). The January Effect Anomaly: Effect on The Returns-Earnings Association. American Journal of Business, 30(2), 114-146.

Efferin, S., \& Hopper, T. (2007). Management control, culture and ethnicity in a Chinese Indonesian company. Accounting, Organizations and Society, 32(3), 223-262.

Engle, R. (2001). GARCH 101: The Use of ARCH/GARCH Models in Applied Econometrics. Journal of Economic Perspectives, 15(4), 157-168.

Evbayiro-osagie, E. (2018). An Analysis of Stock Market Anomalies: Evidence from the Nigerian Stock. Journal of Business School, 1(1), 45-66.

Fama, E. F. (1970). Efficient Capital Markets: A Review of Theory and Empirical Work. The Journal of Finance, 25(2), 383-417.

Floros, C., \& Salvador, E. (2014). Calendar Anomalies in Cash and Stock Index Futures: International Evidence. Economic Modelling, 37, 216-223. 
Geertz, C. (1976). The Religion of Java. Chocago: University of Chicago Press.

Guerard, J. B., \& Chettiappan, S. (2017). Active Quant: Applied Investment Research in Emerging Markets . The Journal of Investing, 26(4), 138-152.

Haggard, K. S., Jones, J. S., \& Witte, H. D. (2015). Black Cats or Black Swans? Outliers, Seasonality in Return Distribution Properties, and The Halloween Effect. Managerial Finance, 41(7), 642-657.

Halari, A. (2017). Calendar Anomalies in Pakistani Stock Returns and Return Volatility. European Journal of Economics.

Halari, A., Helliar, C., Power, D. M., \& Tantisantiwong, N. (2018). Taking Advantage of Ramadan and January in Muslim countries. Quarterly Review of Economics and Finance.

Hamdi, A. (2018, July 5). Fenomena Bulan Selo 1439 H. Retrieved from: www.harianmerdekapost.com/2018/07/fenomena-bulan-selo-1439-h.html

Hermin, S., \& Mahadwartha, P. A. (2018). Javanese lunar calendar effect (Primbon) on abnormal return. Advances in Social Science, Education and Humanities Research, 186.

Hinawati, T. (2016). Efek Hari Libur Idul Fitri terhadap Abnormal Return Saham di Bursa Efek Indonesia. CAKRAWALA, XI(1), 34-50.

Indonesia.go.id. (2020, February 20). Agama. Retrieved from: https://www.indonesia.go.id/ profil/agama

Jaisinghani, D. (2016). An empirical Test of Calendar Anomalies for The India Securities Markets. South Asian Journal Of Global Business Research, 5(1), 53-84.

Kalayil, T., Tyagi, S., Khatun, M., \& Siddiqui, S. (2019). A Risk-Sensitive Momentum Approach to Stock Selection. Economic Annals, LXIV(220), 61-83.

Karaton Ngayogyakarta Hadiningrat. (2019, April 2). Kalender Jawa Sultan Agungan. Retrieved from: https://www.kratonjogja.id/ragam/21/kalender-jawa-sultan-agungan

Kumar, S., \& Pathak, R. (2016). Do The Calendar Anomalies Still Exist? Evidence from Indian Currency Market. Managerial Finance, 42(2), 136-150.

Latif, A.A.A. (2016). Spiritualitas Petungan: Konstruk Psikologis Penentuan Waktu Pernikahan pada Orang Jawa. Prosiding Seminas Nasional Psikologi Indigenous Indonesia 2016, 1-17.

Latif, M., Arshad, S., Fatima, M., \& Farooq, S. (2011). Market Efficiency, Market Anomalies, Causes, Evidences, and Some Behavioral Aspects of Market Anomalies. Research Journal of Finance and Accounting, 2(9), 1-14.

Levy, H. (1996). Introducing to Investment. Nashville: South-western College Publishing.

Liu, W. H. (2013). Lunar Calendar Effect: Evidence of The Chinese Farmer's Calendar on The Equity Markets in East Asia. Journal of the Asia Pacific Economy, 18(4), 560593.

Lobão, J. (2019). Seasonal Anomalies in The Market for American Depository Receipts. Journal of Economics, Finance and Administrative Science, 24(48), 241-265.

MA, S. (2018). The Efficiency of China's Stock Market (A. Chen \& S. Song (eds.). Routledge.

Mills, T. C., \& Coutts, J. A. (1995). Calendar effects in the London Stock Exchange FT SE indices. The European Journal of Finance, 1(1), 79-93.

Mulder, N. (1994). The Ideology of Javanese - Indonesian Leadership. Curzon Press. 
Helanda \& Suryani, The Phenomenon of The Month of Sela....

Munusamy, D. (2018). Islamic Calendar and Stock Market Behaviour in India. International Journal of Social Economics, 45(11), 1550-1566.

Munusamy, D. (2019). Does Ramadan Influence The returns and Volatility? Evidence from Shariah Index in India. Journal of Islamic Accounting and Bussiness Research.

Musnadi, S., Faisal, \& Majid, M. S. A. (2018). Overreaction and Underreaction Anomalies in The Indonesian Stock Market: A Sectoral Analysis. International Journal of Ethics and Systems, 442-457.

Musonnif, A. (2016). Politik Hukum dalam Perumusan Kalender Islam: Studi Tentang Kebijakan Kalender Nabi Muhammad SAW di Jazirah Arab dan Kalender Sultan Agung di Tanah Jawa. AHKAM, 4(1), 1-22.

Nurfitria, N., \& Hidayati, R. (2011). Analisis Perbedaan Omzet Penjualan Berdasarkan Jenis Hajatan dan Waktu: Studi pada Catering Sonokembang Semarang. 1-28.

Ozkan, N. (2017). Hijri Calendar Effect in Borsa Istanbul Gold Market and Turkey's Foreign Exchange Market. Journal of Islamic Accounting and Bussiness Research.

Proudfoot, I. (2007). In Search of Lost Time: Javanese and Balinese Understandings of The Indic Calendar. Bijdragen Tot de Taal-, Land-En Volkenkunde, 163(1), 86-122.

Reddy, K., Qamar, M. A. J., \& Rao, M. (2019). Return Reversal Effect in Shanghai A Share Market. Managerial Finance, 45(6), 698-715.

Riza, K., Rahmawati, E., Rama, F. T., \& Al-maliki, M. A. (2018). Tren Pernikahan di Bulan Pantangan di Sidoarjo. AL-HUKAMA: The Indonesian Journal of Islamic Family Law, 08(1), 117-143.

Rizkianingtyas, T. (2018, September 10). Sama-sama Rayakan Tahun Baru Besok, Inilah Beda Kalender Jawa dengan Islam. Retrieved from: https://www.msn.com/idid/news/other/sama-sama-rayakan-tahun-baru-besok-inilah-beda-kalender-jawadengan-islam/ar-BBN71an

Robiyanto., \& Puryandani, S. (2015). The Javanese Lunar Calendar's Effect on Indonesian Stock Returns. Gadjah Mada International Journal of Business, 17(2), 125-137.

Rohmatillah, M. (2019, July 24). Begini Dampak Musim Kemarau dan Bulan Selo Terhadap Harga Bahan Pokok di Lamongan. Retrieved from: www.timesindonesia.co.id/read /news/221941/begini-dampak-musim-kemaraudanbulan-selo-terhadap-harga-bahan-pokok-di-lamongan

Sahin, S., Topaloglu, E. E., \& Ege, I. (2018). January Effect Revisited: Evidence from Borsa Istanbul and Bucharest Stock Exchange. International Journal of Economics and Finance, 10(1), 159-166.

Samidi. (2016). Tuhan, Manusia, dan Alam: Analisis Kitab Primbon Atassadhur Adammakna. SHAHIH, 1(1), 13-26.

Sarsito, T. (2006). Javanese Culture as The Source of Legitimacy for Soeharto's Government. Asia Europe Journal, 4(3), 447-461.

Seif, M., Docherty, P., \& Shamsuddin, A. (2017). Seasonal Anomalies in Advanced Emerging Stock Markets. The Quarterly Review of Economics and Finance, 66, 169-181.

Shah, N., Shaikh, N. S., \& Bhatti, F. Z. (2017). An Investigation of Islamic Effect on Stock Returns: A Comparative Analysis of Islamic and Non-Islamic State. Research Journal, 1(1), 22-31. 
Shahid, M. N., Sattar, A., Aftab, F., Saeed, A., \& Abbas, A. (2019). Month of Ramadan Effect Swings and Market Becomes Adaptive: A Firm Level Evidence Through Islamic Calendar. Journal of Islamic Marketing.

Swamy, V., \& Dharani, M. (2019). Investor Attention Using The Google Search Volume Index - Impact on Stock Returns. Review of Behavioral Finance, 11(1), 55-69.

Taylor, S. J. (1986). Modelling Financial Time Series. Wiley.

Tjakraningrat, H. (2017). Kitab Primbon Betaljemur Adammakna (Cap-Capan Kaping 67). Soemodidjojo Mahadewa dan CV Buana Raya.

Toit, E. du, Hall, J. H., \& Pradhan, R. P. (2018). The-Day-of-The-Week Effect: South African Stock Market Indices. African Journal of Economic and Management Studies, 9(2), 197-212.

Uchoa, P. (2018, September 17). Krisis ekonomi 2008 dan keadaannya di sejumlah negara, termasuk Indonesia, 10 tahun kemudian. Retrieved from: BBC.Com. https://www.bbc. com/indonesia/dunia-45495304

Wahyudi, M. Z. (2014, November 6). Kalender Jawa, Akulturasi Budaya Islam-Hindu. Retrieved from: https://sains.kompas.com/read/2014/11/06/20363101/Kalender.Jawa. Akulturasi.Budaya.Islam-Hindu.?page=all\#page4.

Wasiuzzaman, S., \& Al-Musehel, N. A. (2017). Mood, Religious Experience and The Ramadhan Effect. International Journal of Emerging Markets, 29(5), 494-519.

Woodward, M. R. (1989). Islam in Java: Normative Piety and Mysticism in The Sultanate of Yogyakarta. Arizona: University of Arizona Press.

World Population Review. (2020, February 20). Muslim Population by Country 2020. Retrieved from: http://worldpopulationreview.com/countries/muslim-population-bycountry/

Zhan, F. (2019). Individualism, Synchronized Stock Price Movements, and Stock Market Volatility. International Journal of Managerial Finance, 15(3), 371-403. 